Private information, capital flows, and exchange rates Jacob Gyntelberg, Mico Loretan and Tientip Subhanij

SNB Working Papers

$12 / 2015$ 


\section{Legal Issues}

\section{DISCLAIMER}

The views expressed in this paper are those of the author(s) and do not necessarily represent those of the Swiss National Bank. Working Papers describe research in progress. Their aim is to elicit comments and to further debate.

\section{COPYRIGHT@}

The Swiss National Bank (SNB) respects all third-party rights, in particular rights relating to works protected by copyright (information or data, wordings and depictions, to the extent that these are of an individual character).

SNB publications containing a reference to a copyright (C) Swiss National Bank/SNB, Zurich/year, or similar) may, under copyright law, only be used (reproduced, used via the internet, etc.) for non-commercial purposes and provided that the source is mentioned. Their use for commercial purposes is only permitted with the prior express consent of the SNB.

General information and data published without reference to a copyright may be used without mentioning the source. To the extent that the information and data clearly derive from outside sources, the users of such information and data are obliged to respect any existing copyrights and to obtain the right of use from the relevant outside source themselves.

\section{LIMITATION OF LIABILITY}

The SNB accepts no responsibility for any information it provides. Under no circumstances will it accept any liability for losses or damage which may result from the use of such information. This limitation of liability applies, in particular, to the topicality, accuracy, validity and availability of the information.

ISSN 1660-7716 (printed version)

ISSN 1660-7724 (online version)

(C) 2015 by Swiss National Bank, Börsenstrasse 15,

P.O. Box, $\mathrm{CH}-8022$ Zurich 


\title{
Private information, capital flows, and exchange rates*
}

\author{
Jacob Gyntelberg ${ }^{\dagger} \quad$ Mico Loretan ${ }^{\ddagger} \quad$ Tientip Subhanij $^{\S}$
}

September 2015

\begin{abstract}
We demonstrate empirically that not all international capital flows influence exchange rates equally. Capital flows induced by foreign investors' transactions in local stock markets have an impact on exchange rates that is both economically significant and permanent, whereas capital flows induced by foreign investors' transactions in the local government bond market do not. We relate the differences in the price impacts of capital flows to differences in the amounts of private information conveyed by these flows. Our empirical findings are based on novel, daily-frequency datasets on prices and quantities of all transactions undertaken by foreign investors in the stock, bond, and onshore FX markets of Thailand.
\end{abstract}

JEL classification: C22, E58, F31, F37, G14.

Keywords: Order flow, private information, exchange rate models, market microstructure, emerging markets.

\footnotetext{
${ }^{*}$ The authors thank Carol Osler, Eli Remolona, and Andreas Schrimpf for detailed discussions and thorough critiques of earlier versions of this paper. We are also grateful for comments by an anonymous referee, Rabah Arezki, Philippe Bacchetta, Claudio Borio, Mark Carey, Michael King, Luis Marques, Jaime Marquez, Robert McCauley, Pichit Patrawimolpon, Lucio Sarno, Charan Singh, Ken Singleton, Elvira Sojli, Chetan Subramanian, Giorgio Valente, Eric van Wincoop, Clara Vega, Frank Warnock, Jonathan Wright, Pınar Yeşin, Jun Yu, and seminar participants at the Bank of Thailand, the Federal Reserve Board, the Fourth Central Bank Workshop on the Microstructure of Financial Markets, the Bank for International Settlements, the Swiss National Bank, the University of Warwick Business School, the 16th Securities and Financial Markets Conference in Kaohsiung, the Reserve Bank of New Zealand, the International Monetary Fund, Singapore Management University, and the Indian Institute for Management Bangalore. Eric Chan provided valuable research assistance. We thank the Bank of Thailand's Data Management Group and the Stock Exchange of Thailand's Research Institute for providing much of the data used in this study. An earlier version of this paper was completed while Jacob Gyntelberg was with the Bank for International Settlements in Basel, Switzerland and Tientip Subhanij was with the Bank of Thailand, Bangkok, Thailand. The views expressed in this paper need not reflect those of any other staff or of the principals of the Bank for International Settlements, the Bank of Thailand, Danske Bank, or the Swiss National Bank. All remaining errors are our own.

${ }^{\dagger}$ Head of C\&I Capital and Regulatory Strategy, Danske Bank, Copenhagen, Denmark; jacob.gyntelberg@danskebank.dk.

${ }^{\ddagger}$ Corresponding author. Economic Advisor, Monetary Policy Analysis Group, Swiss National Bank, Zurich, Switzerland; mico.loretan@snb.ch.

${ }^{\S}$ Lecturer, College of Management, Mahidol University, Bangkok, Thailand; tientip.subhanij@gmail.com.
} 


\section{Introduction}

The determination of foreign exchange rates has long been an important but empirically challenging topic in international economics. Models that aim to relate foreign exchange (FX) rates directly to macroeconomic fundamentals tend to have disappointing out-of-sample and forecasting properties (Meese and Rogoff, 1983; Cheung et al., 2005). Instead of continuing to try to explain exchange rates primarily as equilibrating trade flows across countries, economists turned to modeling exchange rates as the relative prices of assets denominated in various currencies, with trade flows and financial/capital flows both responding to asset demands and supplies. Moreover, beginning with the work of Glosten and Milgrom (1985), Kyle (1985), and Admati and Pfleiderer (1988), it has been argued that in order to understand the price formation in a financial market more fully, one needs to distinguish between the private and public information sets of market participants. Because published macroeconomic fundamentals constitute public information, models that rely only on macroeconomic fundamentals miss investors' private information. This omission helps explain the disappointing performance of fundamentals-only models.

There is by now broad agreement among researchers that order flow-defined as the difference between buyer-initiated and seller-initiated transaction volumes - in FX markets helps explain exchange rates because it conveys investors' private information. Models of exchange rate determination which include order flow as an explanatory variable - such as the one in Evans and Lyons (2002) - tend to dramatically outperform, in terms of both in-sample goodness of fit and out-of-sample forecasting accuracy, models which rely exclusively on macroeconomic data releases and other forms of public information. ${ }^{1}$ Evans and Lyons (2012) provide a rational expectationsbased model of exchange rate determination, in which order flow matters because it reveals information about future economic fundamentals, and they successfully test the predictions of their model using $6 \frac{1}{2}$ years' worth of weekly frequency data on the order flow undertaken by three categories of investors with a globally active FX dealing bank in the EUR/USD currency pair.

While such studies show convincingly that FX order flow matters because it conveys private information, they do not directly address the question as to where the private information originates. Does the private information originate in the FX market itself, or does it originate elsewhere in the economy and is transmitted to the FX market indirectly, say, in conjunction with transactions that link other financial markets to the FX market? Furthermore, do all FX order flows matter equally for exchange rate determination, i.e., is the private information they convey diffuse, or do some types of order flow matter more than others?

Domestic equity and bond markets are linked with the FX market in part through the transactions of foreign investors. For a foreign investor, cash balances in the country's currency are in general not acquired or sold for their own sake. Instead, they are often bought or sold as a byproduct of the investor's decisions to buy or sell stocks and bonds that are denominated in the domestic currency. This observation applies especially in many emerging market economies,

\footnotetext{
${ }^{1}$ For surveys of the market microstructure literature on the subject of exchange rate determination, see Lyons (2001), Sarno and Taylor (2002), Osler (2009), and King et al. (2013). Rime and Tranvåg (2012) and Duffuor et al. (2012) examine order flow and exchange rate dynamics in selected emerging-market economies. Linkages between private information and capital flows - as opposed to those between private information and exchange rates - are examined by Forbes and Warnock (2012), Broner et al. (2013), and Tille and van Wincoop (2014).
} 
where regulations and market incompleteness frequently prevent foreign investors from holding sizable quantities of cash or short-term money market instruments and in which no suitable off-shore markets exist to acquire or sell the financial assets the investor is interested in.

In this paper we establish empirically that external capital flows that are linked to foreign investors' transactions in the domestic stock market have both an economically significant and permanent impact on exchange rates, whereas capital flows induced by foreign investors' transactions in the government bond market do not. We further find that foreign investors' transactions in the stock market are consistent with them being driven in part by differences in private information, whereas their government bond market transactions are not. The reason for the pronounced differences in the effects of these two types of order flow on the exchange rate therefore appears to be connected to differences in the flows' private information content. Hence, not all order flows are equally important for exchange rate determination; some flows clearly matter far more than others do.

Several previous studies have noticed statistical linkages between foreign investors' order flow in stock markets and returns in the FX market; see, e.g., Goodhart (1988), Brooks et al. (2004), Gehrig and Menkhoff (2004), and Siourounis (2008). Moreover, FX dealers state routinely that they scrutinize their own customers' order flow carefully in order to extract any information that may be relevant for exchange rates. Francis et al. (2006, p. 219) note that "there are important, yet not well understood, dynamic relationships between international equity and currency markets and these are driven by information spillover via the mechanism of currency order flow." Froot and Ramadorai (2005) show that State Street Corporation institutional investor flow data has predictive power for changes in real interest rates at horizons of up to thirty days. Rime et al. (2010) report that order flow carries information about upcoming macro news releases for the euro vis-à-vis the US dollar, the pound, and the yen. Albuquerque et al. (2008) observe that market-wide private information on equity returns helps forecast returns for several currency pairs. Dunne et al. (2010) report that intraday data on returns on the French stock market index and the US dollar-euro exchange rate has significant explanatory power for daily S\&P100 returns. Our empirical work strongly supports the view expressed in these studies, i.e., that private information relevant for FX fluctuations is revealed or conveyed mainly by the portion of order flow that is induced by investors' transactions in the stock market. Relative to these earlier studies, the main contributions of our paper is to establish quantitative magnitudes for these relationships and to demonstrate that they hold both in the short and the long run.

In order to analyze the nature of the linkages between investors' transactions in the FX market and in domestic capital markets, we rely on several novel datasets which, when combined, enable us to distinguish between FX transactions which are driven by investors' equity market transactions, those that are driven primarily by investors' bond market transactions, and a residual component. The datasets consist of nearly two years' worth of all daily-frequency transactions undertaken by foreign investors in the onshore foreign exchange, stock, and bond markets of Thailand. Crucially, the data consist of all buy and sell transactions, rather than merely a (possibly non-representative) subset of investors' transactions. We also exploit knowledge of institutional features of financial markets in Thailand, such as settlement practices and regulations that strictly limit the size of foreign investors Thai baht-denominated bank balances, because 
these features ensure that foreign investors' aggregate transactions in the stock and bond markets are closely linked with their aggregate transactions in the FX market. Knowledge of these features enables us to construct simple measures of the portions of FX order flow that are driven by investors' stock and bond market transactions, respectively. These constructed series, in turn, enable us to estimate the influence that various components of FX order flow exert on the exchange rate, both contemporaneously and in the long run.

To the best of our knowledge, our study is the first of its kind that analyzes the exchange rate determination puzzle empirically by combining comprehensive datasets on order flow and returns from three separate financial markets - FX, stock, and bond markets - for an entire country. By utilizing data from Thailand, a major emerging market economy, our study also serves to broaden the geographical range of data employed in exchange rate determination studies; most previous studies in this field have used datasets from developed economies. ${ }^{2}$

Our findings are also related to studies that provide evidence as to which types of investors bring private information to the FX market. Osler and Vandrovych (2009) report that order flow generated by leveraged investors, such as hedge funds and banks, have a strong and lasting impact on the exchange rate whereas order flow from unleveraged institutional investors, large corporations, government agencies, and central banks appears to convey little private information. The papers of Fan and Lyons (2003) and Carpenter and Wang (2007) provide evidence that in FX markets, transactions initiated by financial customers convey more information, at least in the short run, than do transactions initiated by commercial customers. If the FX order flow initiated by leveraged investors indeed conveys more private information than does the order flow of other institutional investors, our findings suggest that the reason for this difference lies in the fact stock market induced FX flows may be generated to an important extent by leveraged investors. This view is consistent with investor surveys which report that in Asia hedge funds are more active in equity than in bond markets. Our findings also suggest that non-equity market related FX market transactions may be driven largely by non-leveraged institutional investors and commercial customers.

The fact that foreign investors engage in the generation of private information does not imply that they are either better or worse informed on average than domestic investors are. It also does not imply that foreign investors earn either higher or lower profits on average from their equity market strategies. For our analysis to apply, we only require that there be heterogeneity between foreign and domestic investors with respect to their private information sets in order to give rise to transactions between these investor groups in the stock market and indirectly the FX market. That said, we find that the serial correlation patterns present in foreign investors' order flow in the Stock Exchange of Thailand (SET) indicate that they have, on average, less private information about SET-listed firms than domestic investors have. This finding is consistent with the studies by Choe et al. (2005), Dvořák (2005), Chan et al. (2007), and Taechapiroontong and Suecharoenkit (2011), who report that foreign investors tend to have less private information than resident investors have in the equity markets of Korea, Indonesia, China, and Thailand, respectively.

\footnotetext{
${ }^{2}$ Richards (2005) and Chai-Anant and Ho (2008) provide descriptions of investors' trading behavior and of financial market dynamics in several Asia-Pacific economies. Gyntelberg et al. (2014) examine empirically whether portfolio balance effects may explain returns in both the stock market and the FX market of Thailand.
} 
The remainder of the paper is structured as follows. Section 2 provides an overview of the financial markets of interest and introduces the datasets. Section 3 provides a stylized model that helps interpret the empirical evidence presented in Section 4. Section 5 concludes.

\section{The markets and the data}

In this section, we provide a brief overview of the onshore FX, stock, and government bond markets in Thailand, focusing mainly on aspects of the markets and data that are important for the development of our empirical analysis. We also discuss certain regulatory features of the financial markets in Thailand that induce a relationship between foreign investors' capital market and FX market transactions that is closer in Thailand than in many other economies. ${ }^{3}$

\subsection{Sample period and foreign investor definition}

Throughout the paper, we focus on the transactions of foreign investors. Formally, foreign investors comprise (i) corporations, institutions, funds, financial institutions or juristic persons located outside Thailand; (ii) entities of foreign governments located outside Thailand; (iii) branches and agents of domestic juristic persons located outside Thailand; and (iv) natural persons who reside in Thailand but are not of Thai nationalities and do not have alien identity or residence permits. According to information we received from the Bank of Thailand (BoT) Data Management Group, financial institutions domiciled outside of Thailand are the most active group, with a share well in excess of $90 \%$ of total transactions conducted by foreign investors.

Foreign investors who hold bank balances in Thailand are required to do so by holding so-called nonresident baht accounts, or NRBAs. During the sample period, NRBA-related regulations were broadly stable. ${ }^{4}$ For our study, the most important such regulation is that balances held in NRBAs were not allowed to exceed THB 300 million per nonresident customer at the end of each day. (For the range of exchange rates that prevailed during the sample period, this limit fluctuated between US\$7.1 and US\$8.6 million.) This limit covers all accounts of a given customer with all domestic financial institutions.

If foreign investors in Thailand, as a group, wish to either build up (unwind) their positions in baht-denominated financial assets such as bonds or shares, they can do so in the short run in the following three ways: (i) by drawing down (building up) their existing baht-denominated bank balances held in NRBAs, (ii) by selling (buying) shorter-term fixed income assets, including money market claims, to (from) domestic market participants, and (iii) by engaging in bahtdenominated FX transactions. Because of the stringent limits on allowable balances in NRBAs and a general lack of liquidity in the private money markets in Thailand, foreign investors typically acquire (liquidate) the funds required for the purchase (sale) of baht-denominated shares

\footnotetext{
${ }^{3}$ Additional characterizations of the datasets and further descriptive statistics are given in Gyntelberg et al. (2009) and Gyntelberg et al. (2014).

${ }^{4}$ The NRBA regulations relevant for our study went into effect in Oct. 2004, i.e., just before the start of the sample period.
} 
and bonds by transacting in the onshore FX market. ${ }^{5}$ This institutional feature is one of the keys to our ability to link foreign investors' order flow across markets.

All observations are daily. The data cover the period from the beginning of January 2005 through Friday, 15 December 2006. The data we received initially ran through mid-2008. However, after conducting a preliminary analysis we decided not to use data after mid-December 2006. On Tuesday, 19 December 2006, the Thai authorities imposed additional and very stringent capital control measures, highlighted by a $30 \%$ unremunerated reserve requirement (URR) on nonresident or foreign investors' financial holdings apart from stock market holdings. The introduction of these measures caused a severe structural break in the behavior of financial markets in Thailand. For instance, following the introduction of the URR measures, foreign investors' participation in the onshore financial markets of Thailand dropped off sharply, the volume of offshore baht-dollar trading increased, and a large differential opened up between onshore and offshore baht-dollar quotes. 6

\subsection{The onshore FX market}

The structure of the onshore FX market in Thailand is similar to that in many other countries. There is no single organized exchange that handles FX transactions. Rather, the wholesale market is over-the-counter. Licensed currency dealers, which can be domestic or foreign-owned banks and brokers, provide wholesale FX trading services. ${ }^{7}$ In addition to conducting interdealer transactions, the FX banks also conduct FX purchases and sales with both domestic and foreign "end-users."

The onshore FX market in Thailand is regulated and closely monitored by the BoT. Licensed FX dealers (mostly commercial banks) are required by the BoT to limit their net FX positions in any one currency to no more than $15 \%$ of regulatory capital (individual currency limit) and also to maintain a net overall FX position across all foreign currencies of no more than $20 \%$ of capital (aggregate currency limit) at the end of each day. The position limits tend to be particularly important for the branches of foreign banks that operate in Thailand. Dealers frequently rely on FX swaps to adhere to these limits.

All licensed FX dealing banks must submit detailed reports of all FX transactions to the BoT on a daily basis. In the banks' daily reports, each transaction record states the name of the counterparty, its type ("other dealer," "domestic customer," "nonresident customer," and BoT), the transaction amount in dollar equivalent, the currencies involved (the vast majority of all transactions is in Thai baht vs. U.S. dollars), the applicable exchange rate, and the type of FX transaction. The five types of FX transactions are spot trades (separated further into same-day, "tomorrow" or $T+1$, and "next" or $T+2$ transactions), outright forwards ( $T \geq 3)$, and FX swaps. Each transaction is classified as either a "buy" or a "sell;" because transactions are recorded from

\footnotetext{
${ }^{5}$ Foreign currencies converted into baht by foreign customers are normally, though not necessarily, credited to their NRBAs before being spent on equities and bond securities. Similarly, the proceeds of sales of equities and bonds by foreigners are frequently credited first to NRBAs before being converted into foreign currencies.

${ }^{6}$ Abhakorn and Tantisantiwong (2012) provide a detailed examination of the impact of the URR measures on the performance of various financial markets in Thailand.

${ }^{7}$ At the beginning of 2005, there were 39 licensed FX dealers in Thailand; 21 were domestic financial institutions and 18 were subsidiaries of foreign financial institutions. After a couple of mergers in late 2005, the number of licensed FX dealers in Thailand was 37 during all of 2006 (20 domestic and 17 foreign).
} 
the point of view of the reporting bank, a "buy" consists of a purchase of foreign currency (by far most commonly the U.S. dollar) by the reporter and hence a sale of baht to the counterparty. ${ }^{8}$

The daily-frequency gross and net capital flow series for all five types of FX contracts have been constructed by the BoT. This was done by first aggregating all reported transactions across reporters to obtain the gross flow series, and then taking the difference between aggregate buys and sells to obtain the net flow series. For this study, our access to the aggregate data was limited to the gross and net flows between dealers and their foreign customers. From conversations we held with FX dealers in Thailand, we believe that the vast majority of all "spot-tomorrow", "spot-next", and outright forward transactions between dealers and their customers-both resident and non-resident - is initiated by the customers. Hence, for these contracts our net flow series should match the theoretical concept of order flow, which focuses on which counterparty initiates the transaction, very well. In contrast, FX dealers told us that FX swaps tend to be initiated by either the FX dealing banks or their non-bank customers. In consequence, in the case of FX swaps our net capital flow measure may not be a good proxy for customer order flow. ${ }^{9}$ Transactions between the BoT and FX dealer banks generally consist of intervention operations. To the extent that the BoT's intervention operations conform to the "leaning against the wind" metaphor, the findings we report in this paper would be even more pronounced if BoT intervention had not occurred. ${ }^{10}$

The average daily transaction volume between dealers and their foreign customers was US $\$ 780$ million in 2005 and US $\$ 1,155$ million in 2006. In both 2005 and 2006, two-day spot transactions made up roughly $45 \%$ of the foreign customer total, FX swaps accounted for an additional 33 to $35 \%$, spot-tomorrow transactions contributed 11 to $13 \%$ to the total, and spot-today and outright forwards $(T \geq 3)$ each accounted for about $4 \%$ of the total transaction volume between dealers and their foreign customers. In both 2005 and 2006, all three daily spot FX net capital flow series were positive on average, i.e., foreign customers were net buyers of spot baht in both years. Conversely, in both years foreign customers were net sellers of baht through outright forwards and FX swaps.

As is the case with most other emerging market economies, trading in the onshore FX market in Thailand occurs almost exclusively during Thai business hours; virtually no transactions occur overnight. The bilateral THB/USD spot exchange rate used in this study is as of 7:15 pm Bangkok time. This collection time coincides roughly with the end of the business day in Bangkok, ensuring that the daily FX returns series reflect all relevant intraday economic information without being affected by global market developments that occur after the close of business in the onshore market. ${ }^{11}$

\footnotetext{
${ }^{8}$ The banks' daily transaction records do not contain information on which counterparty - the reporter or the customer - was the initiator of the transaction, on the bid-ask spread, or on whether the transaction took place at the bank's bid or ask quote. In addition, the transaction records do not contain intraday time-stamp information.

${ }^{9}$ This may help explain some of our ancillary findings, such as the fact that net FX swaps purchases by foreign investors do not appear to explain exchange rate fluctuations.

${ }^{10}$ See Bank of Thailand, Financial Markets Operations Group (2005) for an overview of the approach the BoT took to conducting FX interventions during the sample period.

${ }^{11}$ Other data sources generally report daily-frequency FX rates as of $5 \mathrm{pm}$ New York time, i.e., at the conventional end of a 24-hour trading day in major FX markets.
} 


\subsection{The equity market}

Our stock market price data consist of the daily closing values of the SET index, which is the main share price indicator of the Stock Exchange of Thailand. The SET index is market capitalization -weighted and is based on the stock prices of companies listed on the main board of the exchange. The mean daily return of the SET index was very close to zero in both 2005 and 2006. Except for a brief period of heightened global market volatility during May and June 2006, stock price volatility was fairly low and constant during the sample period. As with the FX datasets, we terminate the sample period on 15 December 2006.

We also have daily-frequency gross buy and sell transaction volumes on the SET by foreign investors. ${ }^{12}$ Investors can trade securities on the SET through any of 39 brokerage houses, many of which are foreign-owned. Settlement for equities is performed on a $T+3$ basis. Average daily gross transaction volume (buys+sells) on the SET by foreign investors in 2005 and 2006 was the equivalent of US\$229 million and US\$ 286 million, respectively, or less than a third of average daily gross transactions volumes between dealers and their foreign customers.

\subsection{The bond market}

Foreign investors' participation in the Thai bond markets in 2005 and 2006 was quite limited. Daily transaction volumes by foreign investors averaged US\$ $\$ 5$ million and US\$ 88 million in these two years, amounting to only $15 \%$ and 19\%, respectively, of all bond market trades. In 2005 and 2006, trading volume in the secondary bond markets was overwhelmingly (about 98\%) concentrated in BoT paper and in government bonds and bills. Even though the stock of outstanding corporate bonds in Thailand has grown rapidly in recent years, trading in corporate bonds was very limited during the sample period.

Our bond market dataset consists of daily-frequency buy and sell transaction totals by foreign investors in the secondary bond market. Bond market transactions are classified according to whether they are "outright" (or "ordinary") or "other" transactions. In our sample, "outright" transactions make up about $70 \%$ of all transactions. According to information we received from private-sector dealers and BoT staff, these transactions are mainly associated the one-day $(T+1)$ settlement segment of the spot FX market, although some transactions settle on a $T+2$ or even $T+3$ basis as well. "Other" bond trades tend to occur mainly in connection with banks' financing transactions and settle mostly on a same-day or a $T+1$ basis. They make up about $30 \%$ of the total bond market transaction volume of the banks' foreign customers.

Consistent with market settlement practices, we found that two-day spot FX order flow was related systematically to stock market variables but not to bond market variables. We also found that one-day FX-spot order flow was related systematically to investors' transactions in both the "outright bonds" and "other bonds" categories, but only barely to stock market variables. ${ }^{13}$

\footnotetext{
${ }^{12}$ Albuquerque et al. (2008) used firm-by-firm equity transactions data to construct proxies for firm-specific and market-wide private information. Because of the aggregate nature of our data, we could not perform such calculations and hence cannot distinguish separately between these motives for trading.

${ }^{13}$ The $\mathrm{R}^{2}$ statistic of the regression of the two-day spot FX series on the stock market variables alone was 0.19, and the $\mathrm{R}^{2}$ of the regression of the one-day spot FX series on the bond market variables was 0.11. For comparison, the $\mathrm{R}^{2}$ value for the regression of one-day spot FX order flow on just the stock market variables was only 0.05 .
} 
During the sample period, foreign investors' net daily stock market transactions were nearly uncorrelated with their "outright" bond flows as well as with their "other" bond flows (with correlations below 0.05). In addition, foreign investors' net flows in "outright" and "other" bonds were also only slightly positively correlated with each other, with a correlation coefficient of about 0.15 . Overall, these findings suggest that the three types of domestic capital market transactions are undertaken for different reasons.

\section{Private information and FX markets}

Consider the following, highly stylized setting of the signal extraction problem that FX dealers face in a dealer-based wholesale FX market. The dealers and their non-dealer foreign customers are assumed to have access to the same amounts of public information. We also assume that the arrival process for public information is sufficiently stationary to let the FX market equilibrate in response to public information releases without the dealers having to obtain information about their customers' order flow. In all transactions, foreign investors are assumed to be the "aggressors," or initiators, of financial transactions. By regulation, foreign investors are not allowed to hold substantial amounts of cash, bank balances, or short-term money market instruments. Therefore, foreign investors' net position changes in the domestic stock and government bond markets are closely linked to their net order flow in the FX market. We further assume that investors' order flow in the stock market is based importantly on private information, whereas their order flow in the bond market is based exclusively on public information.

Suppose that a dealer receives a customer order to purchase the domestic currency for dollars at the current quoted price. The dealer then has to decide whether to adjust her bid and ask quotes in response to this order (Bacchetta and van Wincoop, 2006; Dunne et al., 2010). If she believes it is a pure liquidity (or "noise") order, the optimal reaction is not to adjust the quotes other than for liquidity and inventory rebalancing reasons. If the customer order is based on public information, an efficient FX market can determine the new equilibrium exchange rate without dealers having to resort to observing patterns in their customer order flow. Finally, if the customer order flow is based on, or is believed to be based on, private information, the dealer's optimal reaction is to adjust bid and ask quotes in the direction of the trade. Such a customer order to buy baht will lead to an appreciation of the baht.

How might a dealer discern whether a customer's incoming buy order for baht is based on private information? The FX dealer may rely on an important clue: Is the customer more likely to use the proceeds of the baht purchase to acquire bonds or equities in the local capital markets? ${ }^{14}$ If it is the former, the FX transaction that is generated by the bond market transaction-by assumption - represents either a liquidity or a public information-based trade and therefore does not add to the market-relevant information the FX dealer already has. On the other hand, if the trade is induced by an equity market transaction, it is more likely than not based on the investor's private information. It therefore conveys the investor's private information not only to

\footnotetext{
${ }^{14}$ The overwhelming majority of all trades undertaken by foreign investors in Thailand are effected by institutional investors. FX traders are well aware of the investment styles and market specialization of their customers.
} 
Table 1: Autocorrelations in foreign investors' net daily order flow

\begin{tabular}{|c|c|c|c|c|c|c|}
\hline & \multicolumn{5}{|c|}{ Lags (in days) } \\
\hline & & 1 & 2 & 3 & 4 & 5 \\
\hline \multirow[t]{2}{*}{ (1) } & Equities & 0.55 & 0.42 & 0.34 & 0.23 & 0.17 \\
\hline & Bonds & & & & & \\
\hline$(2)$ & Bonds outright & -0.06 & 0.01 & 0.02 & -0.03 & 0.02 \\
\hline (3) & Bonds other & -0.06 & -0.01 & -0.05 & -0.07 & 0.06 \\
\hline \multirow[t]{2}{*}{ (4) } & Bonds, total & 0.04 & 0.02 & -0.01 & -0.06 & 0.02 \\
\hline & Foreign exchange & & & & & \\
\hline$(5)$ & Spot, today & 0.11 & -0.03 & 0.01 & 0.07 & 0.10 \\
\hline (6) & Spot, tomorrow $(T+1)$ & 0.50 & 0.34 & 0.25 & 0.20 & 0.19 \\
\hline (7) & Spot, next $(T+2)$ & 0.29 & 0.23 & 0.14 & 0.14 & 0.12 \\
\hline (8) & Forwards & 0.07 & 0.00 & 0.08 & 0.08 & 0.00 \\
\hline (9) & Sum of spot and forwards ("FX_SPOT") & 0.21 & 0.14 & 0.05 & 0.02 & 0.14 \\
\hline (10) & FX Swaps & 0.34 & 0.28 & 0.26 & 0.28 & 0.26 \\
\hline
\end{tabular}

Source: Bank of Thailand, CEIC, BIS, authors' calculations.

the stock market but also to the FX market. In the aggregate, these transactions will therefore generate a permanent exchange rate reaction.

Our stylized story of how investors' private information is discerned by FX dealers and how it affects prices rests on the hypothesis that private information affects investors' transactions significantly in some capital markets, such as the stock market, but less so in others, such as the government bond market. Given that private information, by its very nature, is not observed directly, how might one test this hypothesis? Following the reasoning of Brennan and Cao (1997), "flow momentum" - or non-zero serial correlation in purchases or sales of assets by a subset of investors - in an otherwise efficient financial market may be an indication that these investors' decisions are affected by disparities in private information. Conversely, an absence of flow momentum may indicate that the private information set of foreign investors is not meaningfully different from that of domestic investors. Applied to our datasets, then, if our identifying assumptions are empirically relevant, foreign investors' transactions in the stock market of Thailand (and, indirectly, in at least one segment of the onshore FX market) should exhibit nonzero serial correlation, whereas their transactions in the bond market should not.

Line (1) in Table 1 shows that foreign investors' daily net equity trades were indeed characterized by positive serial autocorrelation, or positive flow momentum, during the sample period. ${ }^{15}$ This pattern is consistent with these investors having, on average, less private information than domestic investors in the stock market have. In contrast, there is very little serial correlation in foreign investors' net daily bond market transactions (cf. lines (2) to (4) in the table), ${ }^{16}$ which is indicative of a lack of private information disparities. Given that bond market transactions in Thailand are heavily concentrated in government and central bank paper, and given that it is not

\footnotetext{
${ }^{15}$ The null hypothesis that the first five autocorrelation coefficients of the series of daily net equity purchases are jointly zero is rejected strongly.

${ }^{16}$ The null hypothesis that the first five autocorrelation coefficients of the series of combined daily bond purchases - cf. line (4) - are jointly zero can not be rejected.
} 
plausible to assume that foreign investors suffer a significant information disadvantage relative to domestic investors (at least at daily horizons) with regard to government paper, the lack of serial correlation is not surprising from a market microstructure perspective. In addition, lines (6) and (7) of Table 1 show that foreign investors' transactions in the one-day spot and two-day spot segments of the FX market also exhibit positive serial correlation during the sample period. ${ }^{17}$

Taken together, we interpret these empirical regularities as a strong indication that while foreign investors' transactions in the stock market and certain segments of the FX markets are determined in part by disparities in private information, this is not the case for their transactions in the bond market. We make use of these empirical regularities in the following section, when we trace the effects of bond and stock market flows in the FX market.

\section{Empirical results}

The proposition we wish to test is that FX order flow induced by investors' stock market transactions has a statistically significant and permanent effect on the exchange rate, whereas FX order flow induced by bond market transactions does not. Table 2 provides the acronyms and brief descriptions of all variables used in this section. To simplify the exposition and discussion of our empirical work, we combine all FX order flow series except for FX_SWAP into a single series which we call FX_SPOT. None of the findings regarding the differences in influence of stock and bond market induced order flow are changed by affected by simplification. ${ }^{18}$

We do not observe directly whether a customer's FX transaction is associated with a transaction in the domestic stock or bond markets. ${ }^{19}$ We are also not able to reconstruct the FX dealers' real-time information about their customers' transactions. Relative to the FX dealing banks, however, we possess the important informational advantage of having complete (rather than only partial) data on each day's aggregate order flow effected by all foreign customers in the FX, stock, and bond markets. Having these detailed data from three separate financial markets lets us construct proxies for the subsets of foreign investors' FX order flows that are driven by their stock and bond market transactions. ${ }^{20}$

We employ a two-stage procedure to estimate the contemporaneous impact of FX order flow driven by investors' transactions in the equity and bond markets. In the first stage, we construct proxies for the portions of daily FX order flow that are driven by stock and bond market variables. In the second stage, we regress daily baht-dollar returns on these proxy variables as well as on additional control variables and test the null hypothesis that the coefficients of the constructed regressors are equal. The reported standard errors use the method proposed by Newey and West

\footnotetext{
${ }^{17}$ The contemporaneous correlation between foreign investors' daily net transactions in the stock and bond markets is 0.05 , which is not statistically different from zero at the $90 \%$ confidence level.

${ }^{18}$ For empirical tests using the individual FX series, see Gyntelberg et al. (2009).

${ }^{19}$ If each transaction record submitted by the FX dealing banks to the BoT contained information to denote whether the customer's FX transaction was associated with a transaction in (i) the domestic stock market, (ii) the bond market, or (iii) neither of the above, it would of course be straightforward to test our hypothesis directly: One would run an order flow regression with FX returns as the dependent variable and the three FX order flow series as regressors.

${ }^{20}$ The practice of splitting a time series into two components - one constructed as the fitted part from a preliminary or first-stage regression and the other defined as the residual from that regression - and using both the fitted and residual components as explanatory variables in lieu of the original series dates back at least to the work of Barro (1977).
} 
Table 2: Variable mnemonics and descriptions

All order flow series refer to net daily transactions between banks and foreign customers. Order flow is defined as the difference between banks' "buy" and "sell" transactions with their customers. The order flow series are measured in USD millions.

\begin{tabular}{ll}
\hline Variable name & Description \\
\hline THB & First difference of log of baht-dollar exchange rate \\
SET & First difference of log SET index, in dollar terms \\
STOCKS & Order flow, stocks \\
BONDS_OUTRIGHT & Order flow, "outright" bonds \\
BONDS_OTHER & Order flow, "other" bonds \\
BONDS & Order flow, sum of "outright" and "other" bond order flow series \\
FX_SPOT & Order flow, all FX transactions except swaps \\
FX_SWAP & Order flow, all FX swap transactions \\
FX_SPOT_STOCK & Portion of FX_SPOT series that is explained by stock market order flow \\
FX_SPOT_BOND & Portion of FX_SPOT series that is explained by bond market order flow \\
FX_SPOT_RESID & Residual: FX_SPOT - FX_SPOT_STOCK - FX_SPOT_BOND \\
\hline
\end{tabular}

(1987) to adjust for possible heteroskedasticity and serial correlation in the regression errors. The models passed several tests for structural breaks and other forms of mis-specification.

\subsection{FX order flow induced by stock and bond market transactions}

To determine if FX order flow is affected by transactions in the stock and bond market, we first regressed the FX_SPOT order flow series on bond and stock market order flow variables. The results of this regression are shown in Table 3. The regression estimates show that a US\$ 100 million increase in foreign investors' net purchases of shares on the stock market was associated, on average, with a contemporaneous increase of about US\$107 million in net purchases of baht. This point estimate is statistically significant from 0 but not from 1 , Put differently, one can not reject the hypothesis that investors stock market purchases are associated one-for-one with transactions in the spot and forward segments of the FX market. In contrast, a US\$ 100 million increase in purchases of bonds was associated with only US\$ 44 million in additional baht purchases. ${ }^{21}$

To be sure, we do not claim that transactions in the stock market and FX market are driven solely by investors' private information. Their transactions could (and should) also be driven by public information releases in Thailand as well as by hedging and liquidity needs that are unrelated to economic conditions in Thailand. However, for the purposes of our analysis, it is not actually necessary to include proxies for public information. Because the public and private information sets are orthogonal by construction, we appeal to a well known result in econometrics - that the omission of regressors that are orthogonal to the included regressors does not cause omitted variable bias - to conclude that the non-inclusion of variables that proxy for

\footnotetext{
${ }^{21}$ In addition to this regression, we also ran regressions which included contemporaneous SET index returns (SET) and the first three lags of the STOCKS and BONDS series as additional regressors. While the coefficient on SET was statistically significant, its inclusion (or omission) does not affect the coefficients or standard errors of the order flow variables in the regression shown above. None of the lagged additional regressors were statistically significant. Put differently, the relationships between the order flow variables are mainly contemporaneous.
} 
Table 3: Influence of stock and bond market transactions on FX flows

Dependent variable: FX_SPOT, i.e., all customer FX market order flow except FX swaps.

Estimation method: Ordinary least squares.

The standard errors are calculated using the Newey-West method with a Bartlett kernel and the lag length parameter set to 6 . The $p$-values denote the significance of the associated $t$-statistics for the two-sided null hypothesis that the coefficient in question is zero.

\begin{tabular}{lcccr}
\hline Regressor & Coefficient & Std. Error & $t$-statistic & $p$-value \\
\hline C & 28.022 & 7.856 & 3.57 & 0.000 \\
STOCKS & 1.071 & 0.274 & 3.91 & 0.000 \\
BONDS & 0.439 & 0.177 & 2.49 & 0.013 \\
\hline & $\mathrm{R}^{2}$ & 0.13 & F-stat. & 34.61 \\
& Adj. $\mathrm{R}^{2}$ & 0.13 & Prob. F-stat. & 0.00
\end{tabular}

Number of observations: 472 after adjustments

public information does not create an omitted-variable bias in the estimates of the coefficients and standard errors of the included regressors.

Using the coefficient estimates reported in Table 3, we constructed proxies for the portions of daily FX spot order flow that are driven by (a) stock market order flow, called FX_SPOT_STOCK, and (b) bond market order flow, called FX_SPOT_BOND. Because FX_SPOT_STOCK and FX_SPOT_BOND are affine functions of STOCK and BOND, respectively, they have the same serial correlation properties as the variables they are computed from, i.e., FX_SPOT_STOCK features significant autocorrelation whereas FX_SPOT_BOND does not. Moreover, they are only very weakly contemporaneously correlated with each other. The residual from the first-stage regression reported in Table 3, called FX_SPOT_RESID, serves as a third regressor in the order flow regression model and the vector autoregressive (VAR) that are examined in the following two subsections. ${ }^{22}$ By construction, the residual-based series, FX_SPOT_RESID, is not correlated with either FX_SPOT_STOCK or FX_SPOT_BOND.

\subsection{Order flow regression}

We next ran a regression with baht-dollar returns, THB, as the dependent variable and the two fitted FX order flow series, FX_SPOT_STOCK and FX_SPOT_BOND, as well as the residual order flow series from the first stage regression, FX_SPOT_RESID, as the explanatory variables. The results of this regression are shown in Table $4 .{ }^{23}$

We estimated the order flow regression using a two-stage least squares method, using instruments the lagged exchange rate changes and equity market returns and for the fitted regression to obtain consistent estimates of the reported standard errors. The use of two-stage least squares is necessary because we use constructed rather than directly observed regressors; the resulting

\footnotetext{
${ }^{22}$ The first through fifth serial correlation coefficients of the series FX_SPOT_RESID are $0.12,0.02,-0.03,-0.03$, and 0.10 , respectively. The null hypothesis that these five serial correlation coefficients are jointly zero can be rejected at the $5 \%$ level, though not at the $1 \%$ level.

${ }^{23}$ The inclusion of additional regressors that serve as proxies for public information led to a minor increase in the model's overall goodness of fit, but doing so did not change any of the quantitative and qualitative results for the order flow regressors, which are of primary interest in this study.
} 
Dependent variable: THB, log first difference of the baht/dollar exchange rate. Negative values of the regression coefficients imply an appreciation of the baht versus the dollar.

Estimation method: Two-stage least squares.

The standard errors are calculated using the Newey-West method, with a Bartlett kernel and a lag length of 6 , to adjust for possible heteroskedasticity and serial correlation in the regression errors. The $p$-values denote the significance of the associated $t$-statistics of the two-sided null hypothesis that the coefficient in question is zero.

\begin{tabular}{llccr}
\hline Regressor & Coefficient & Std. Error & $t$-statistic & $p$-value \\
\hline C & 0.001 & 0.000 & 1.35 & 0.178 \\
FX_SPOT_STOCK & $-1.31 e-5$ & $0.60 e-5$ & -2.19 & 0.030 \\
FX_SPOT_BOND & $-0.55 e-5$ & $0.61 e-5$ & -0.89 & 0.373 \\
FX_SPOT_RESID & $-0.11 e-5$ & $0.39 e-5$ & -0.28 & 0.781 \\
\hline & $\mathrm{R}^{2}$ & 0.11 & F-stat. & 2.63 \\
& Adj. $\mathrm{R}^{2}$ & 0.11 & Prob. F-stat. & 0.05
\end{tabular}

Number of observations: 436 after adjustments

statistical dependence between the regressors and the error term of the second-stage regression renders inference using OLS-based standard errors invalid. ${ }^{24}$

The main empirical result is that - even after controlling for momentum effects and the impact of portfolio adjustments to equity market returns - the coefficient of the stock-market induced portion of order flow is statistically significant. The coefficient point estimate indicates that, during the sample period, a net increase of US $\$ 100$ million in purchases of baht related to investors' stock market transactions was associated with a same-day appreciation of the baht against the U.S. dollar of ca. $0.13 \%$. Importantly for us, the coefficient of the stock-market induced portion of order flow is the only one that is statistically significant; the coefficients on the bond-market portion and the residual part of the FX order flow are both not statistically different from zero. ${ }^{25}$

\subsection{Longer-run impact of portions of FX order flow on the exchange rate}

To analyze the longer-run impact of FX order flow driven by investors' transactions in the equity and bond markets, we estimated a four-variable vector autoregressive (VAR) model consisting of FX_SPOT_STOCK, FX_SPOT_BOND, and FX_SPOT_RESID - i.e., the components of FX spot order flow that are driven by stock and bond market variables and the residual component - and THB, i.e., baht-dollar returns. Three lags of all variables were included. We orthogonalized the impulse response functions using the Cholesky decomposition method, letting innovations in the order flow series drive FX returns, but not vice versa. The three order flow series were found to be

\footnotetext{
${ }^{24}$ Mishkin (1982) and Pagan (1984) examine the econometric issues that arise when using fitted regressors. Pagan shows that whereas the coefficients as well as the standard errors of the residual regressors would be consistently estimated by OLS, the OLS-based estimates of the standard errors of the fitted regressors would be inconsistent. We therefore used instruments for the fitted regressors and specified the second-stage regression equation as recommended by Pagan.

${ }^{25}$ Note that the three order flow series are measured in the same units. Hence, the differences in coefficient estimates is not related to the fact that, during the sample period, the daily volume of stock market transactions was larger than that of bond market transactions.
} 
weakly exogenous to the baht-dollar returns series. Our choice of ordering the variables in the Cholesky decomposition is thus supported by the data. ${ }^{26,27}$

The associated impulse response functions (IRFs) and cumulative response functions (CRFs), which trace the dynamic effects of innovations in the three components of FX_SPOT on the exchange rate out to ten business days, are shown in Figure $1 .^{28}$ The IRF shown in the top-left panel of the figure indicates that a shock to the FX order flow component that may be attributed to equity market variables has a negative and statistically significant initial impact on baht returns; ${ }^{29}$ the FX rate response on subsequent days is close to zero and (with the exception of day 4) not statistically significant. The cumulative impact of such a shock, shown in the top-right panel of the figure, is a permanent and statistically significant appreciation of the baht, i.e., the initial impact of an innovation in FX order flow is not reversed if the innovation is driven by stock-market flows.

In contrast, both the initial and the cumulative impacts of FX order flow innovations driven by bond market transactions are close to zero as well as not statistically significant; cf. the middle row of Figure 1. Thus, the finding that bond-induced FX order flow does not influence FX rates holds in the long run as well as contemporaneously. And, while the initial response to a shock to the residual portion of FX order flow - cf. the bottom row of the figure - is a statistically significant appreciation of the baht, this effect is reversed over the next four business days. In consequence, the cumulative response of THB/USD to this type of shock is not statistically different from zero after the first four days.

Taken together, these results demonstrate that the portion of FX order flow that reflects investors' transactions in the stock market has economically and statistically significant shortand long-run effects on the exchange rate, whereas the two other portions generate at most transitory effects. Given the serial correlation patterns present in overall FX, stock, and bond order flows that were noted in Table 1 as well as in the stock, bond, and residual portions of FX order flow, we interpret these results as showing that (a) the private information conveyed by FX_SPOT_STOCK accounts for the large and permanent effect of this order flow series on the exchange rate and (b) the lack of private information in FX_SPOT_BOND explains the absence of any influence on the exchange value of the baht.

\subsection{Possible alternative explanations}

We now consider two possible alternative explanations of our finding that only equity-driven FX order flow has a large and permanent effect on the exchange rate: differences in the hedging of FX risk across stock and bond holdings, and the influence of carry trade investments.

\footnotetext{
${ }^{26}$ Killeen et al. (2006) also found weak exogeneity of FX order flow with respect to exchange rates for the case of the French franc/Deutsche mark exchange rate. To check the robustness of our conclusions, we re-estimated the VAR with 6 instead of 3 lags, and we also constructed the IRFs and CRFs using a "structural" decomposition in addition to the Cholesky decomposition. Our conclusions were not affected by these alternative specifications.

${ }^{27}$ Because the three order flow components are either not at all or only very weakly correlated with each other, the ordering of the three series in the Cholesky decomposition method also does not affect our results.

${ }^{28}$ At time horizons longer than ten days, the functions are essentially zero and therefore do not provide additional information about the system's longer-horizon dynamic properties.

${ }^{29}$ Recall that a baht appreciation versus the dollar means that fewer baht are needed to buy one dollar. Hence, a baht appreciation is expressed as a negative return on THB/USD.
} 
Figure 1: THB/USD exchange rate responses to FX order flow shocks

The left-hand panels show impulse response functions (IRFs), and the right-hand panels show cumulative response functions (CRFs) of the THB/USD exchange rate to one-standard-deviation shocks in three types of FX order flow: those induced by stock-related trading (top row), bond-related trading (middle row), and the residual series (bottom row).

A baht appreciation vis-à-vis the dollar is shown as a negative response. The units of measurement are business days on the horizontal axes and percent changes on the vertical axes. Dashed lines denote two-sided $95 \%$ confidence bands.

(a) Impulse and cumulative impact of shocks to stock-induced FX flow
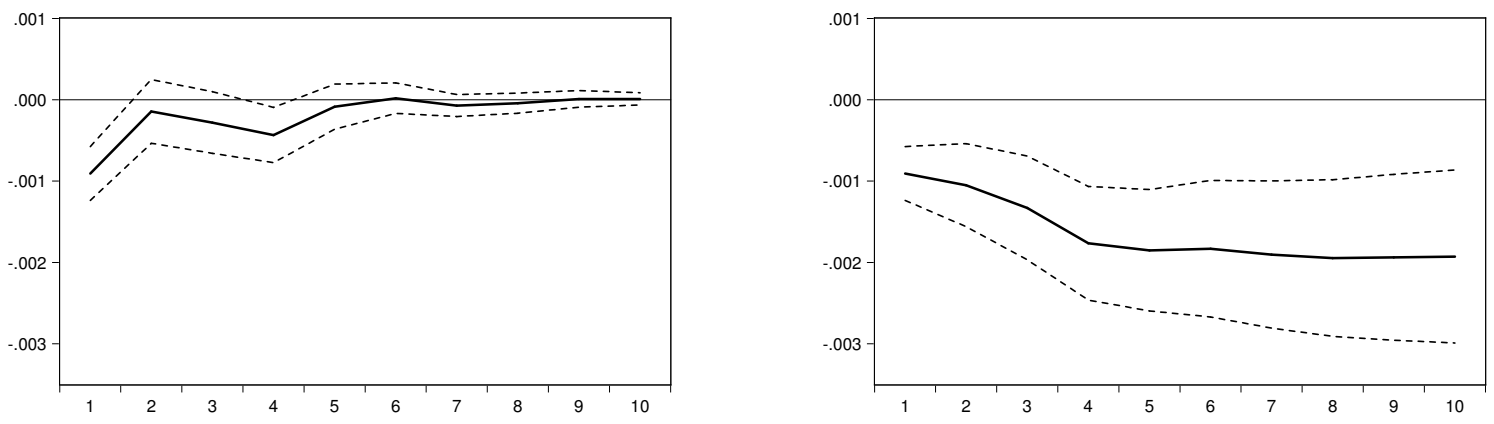

(b) Impulse and cumulative impact of shocks to bond-induced FX flow
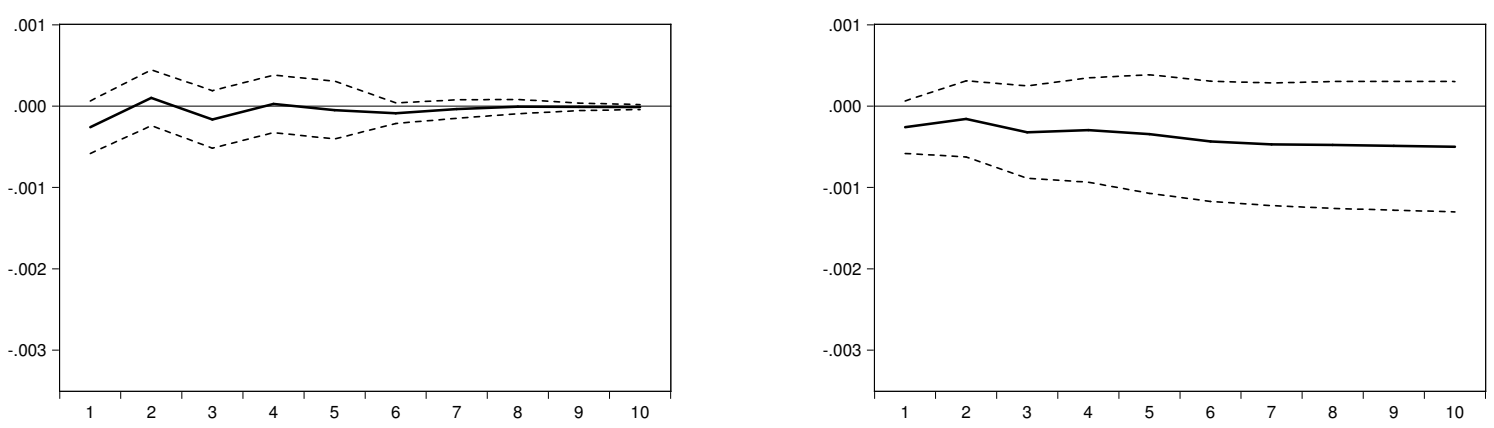

(c) Impulse and cumulative impact of shocks to residual FX flow
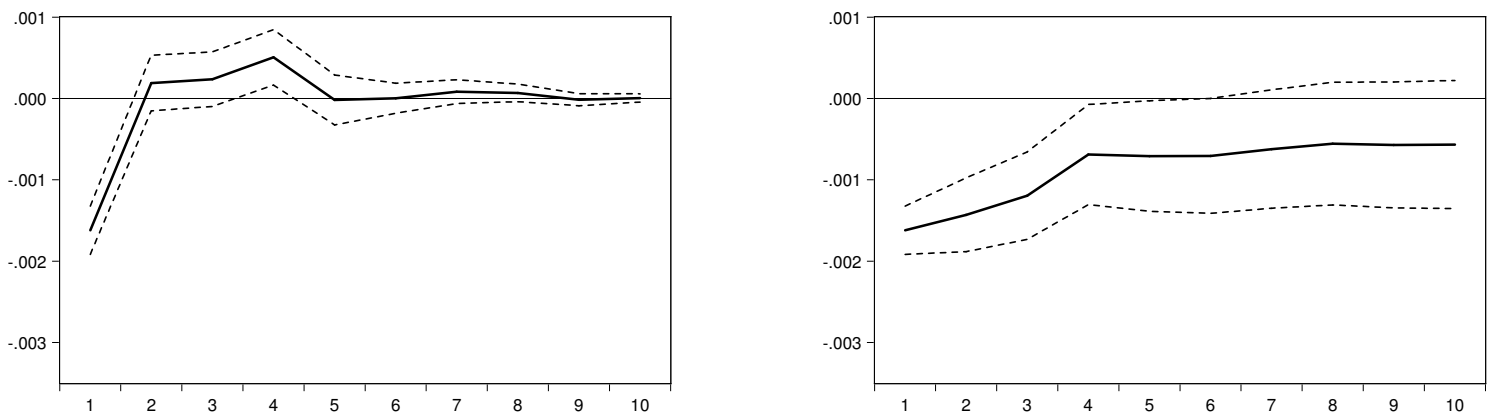
Table 5: Determinants of FX swap order flow

Dependent variable: FX_SWAP, the net FX swap transactions conducted between banks and foreign investors.

Estimation method: Ordinary least squares.

The numbers in the $p$-value column denote the significance of the associated $t$-statistics against the two-sided alternative that the coefficients in question are different from zero.

\begin{tabular}{|c|c|c|c|c|}
\hline Regressor & Coefficient & Std. Error & $t$-statistic & $p$-value \\
\hline $\mathrm{C}$ & -31.52 & 6.983 & -4.513 & 0.000 \\
\hline STOCKS & -1.346 & 0.186 & -7.242 & 0.000 \\
\hline BONDS_OUTRIGHT & -0.168 & 0.182 & -0.923 & 0.356 \\
\hline \multirow[t]{3}{*}{ BONDS_OTHER } & -0.464 & 0.198 & -2.342 & 0.020 \\
\hline & $\mathrm{R}^{2}$ & 0.185 & F-stat. & 9.99 \\
\hline & Adj. $R^{2}$ & 0.167 & Prob. F-stat. & 0.00 \\
\hline Number of obser & $: 406$ after ac & nts & & \\
\hline
\end{tabular}

One possible alternative explanation of our finding is that FX risk incurred by equities might be left unhedged by investors, whereas it is hedged if it is incurred by bonds. In the Thai baht FX market, FX risk is typically hedged mainly through FX swaps. Thus, if there was hedging of bond-related FX risk but not of equity-related FX risk, FX swap order flow should be driven more by bond flows than by equity flows.

In Table 5, we report the results of a regression of the FX_SWAP series on the contemporaneous order flows in the equity, "outright" bond, and "other" bond markets. The main result is that foreign investors appear to use FX swaps to hedge both their equity and their "outright" bond transactions. In fact, the point estimate of the coefficient on the stock market order flow series $(-1.346)$ is larger in absolute value than that on the "outright" bond order flow series $(-0.168)$; the difference between the two coefficient estimates is statistically significant. This indicates that differences in hedging behavior can not explain our finding.

As is also shown in Table 5, the coefficient on the BONDS_OTHER order flow series is -0.464 , i.e., about one half of the FX risk associated with "other" bond transactions is hedged through offsetting FX swap transactions. This is consistent with anecdotal evidence that "other" bond market transactions are used mainly in conjunction with banks' local money market operations.

Another possible alternative explanation for our finding that bond market order flow does not appear to affect the exchange rate is that foreign investors could be buying and selling Thai bonds as part of a carry trade strategy. During the sample period, Thailand experienced robust economic growth and offered attractive interest rate differentials to investors. If foreign investors' bond transactions were mainly carry trades, the induced FX order flow should not contain private information and hence should not affect the exchange rate systematically. However, we found that neither contemporaneous nor lagged fluctuations in baht-dollar interest rate differentials were statistically significant drivers of bond market transactions. Thus, carry trade activity-by 
itself - can not explain the lack of a significant relationship between bond-market induced FX order flow and exchange rate fluctuations. ${ }^{30}$

We also examined the possibility that fluctuations in the dollar-yen cross rate could be an important driver of carry trade activity. Over the sample period as a whole, we did find that fluctuations in dollar-yen helped explain, in a statistical sense, contemporaneous baht-dollar movements; a 1 percent daily appreciation of the yen against the dollar was associated, on average, with a same-day 0.3 percent appreciation of the baht against the dollar. However, the inclusion of yen-dollar returns as an additional regressor in the order flow regressions did not perceptibly change either the coefficients or the standard errors of the order flow variables. Hence, even if carry trades had been significant during the sample period, they would not affect our findings regarding either the empirical importance of FX order flow induced by stock market transactions or the lack of empirical importance of FX order flow induced by bond market transactions.

\section{Concluding remarks}

In this paper, we have argued that investors' private information related to the stock market helps explain exchange rate fluctuations. We tested this proposition using daily-frequency data from three financial markets in Thailand, and we found strong evidence in favor of the proposition. To paraphrase a famous phrase of Animal Farm (Orwell, 1945), some capital flows are more equal than others when it comes to affecting exchange rates: Only the relatively small portion of FX flows that is driven by investors' transactions in the stock market has a lasting effect on the exchange rate. Given that the observed flows in the stock and FX markets are consistent with information asymmetry between domestic and foreign investors, we infer that the reason the stock market-induced capital flows have a lasting effect on the exchange rate is that they convey investors' private information, not only to the stock market but also to the FX market. In contrast, the much larger portion of FX flows that is not explained by stock market variables plays at most a transitory role in determining the exchange rate. Taken together, these findings strongly suggest that FX order flow is relevant for the exchange rate if it reflects investors' private information about individual firms and the corporate sector as a whole.

Our findings also suggest that data collection efforts for external capital flows could be made more informative if capital flows were categorized according to their private information content. Having such data would enable economists and policy makers to distinguish more readily between information-driven flows and those that are driven by liquidity or "noise" trades. Our results suggest that analysts should focus their attention on those flows that convey private information.

\section{References}

Abhakorn, P. and Tantisantiwong, N. (2012). A reexamination of capital controls' effectiveness: Recent experience of Thailand. Journal of Asian Economics, 23(1):26-38.

Admati, A. R. and Pfleiderer, P. (1988). A theory of intraday patterns: Volume and price variability. Review of Financial Studies, 1(1):3-40.

\footnotetext{
${ }^{30}$ See Sarno and Sojli (2009) and Sarno and Valente (2009) for a review of the "feeble" or "footloose" connections between exchange rates and economic fundamentals such as interest rate differentials.
} 
Albuquerque, R., de Francisco, E., and Marques, L. B. (2008). Marketwide private information in stocks: Forecasting currency returns. Journal of Finance, 68(5):2297-2343.

Bacchetta, P. and van Wincoop, E. (2006). Can information heterogeneity explain the exchange rate determination puzzle? American Economic Review, 96(3):552-576.

Bank of Thailand, Financial Markets Operations Group (2005). Foreign exchange policy and intervention in Thailand. In Foreign Exchange Market Intervention in Emerging Markets: Motives, Techniques and Implications. Proceedings of the BIS Deputy Governors' Meeting held on 2-3 December 2004, BIS Papers 24, pages 276-282. Bank for International Settlements, Basel.

Barro, R. J. (1977). Unanticipated money growth and unemployment in the United States. American Economic Review, 67(2):101-115.

Brennan, M. J. and Cao, H. H. (1997). International portfolio investment flows. Journal of Finance, 52(5):1851-1880.

Broner, F., Didier, T., Erce, A., and Schmukler, S. L. (2013). Gross capital flows: Dynamics and crises. Journal of Monetary Economics, 60(1):113-133. Carnegie-NYU-Rochester Conference.

Brooks, R., Edison, H. J., Kumar, M. S., and Sløk, T. M. (2004). Exchange rates and capital flows. European Financial Management, 10(3):511-533.

Carpenter, A. and Wang, J. (2007). Sources of private information in FX trading. Pacific-Basin Finance Journal, 15(2):173-194.

Chai-Anant, C. and Ho, C. (2008). Understanding Asian equity flows, market returns, and exchange rates. Working Paper 245, Bank for International Settlements, Basel.

Chan, K., Menkveld, A. J., and Yang, Z. (2007). The informativeness of domestic and foreign investors' stock trades: Evidence from the perfectly segmented Chinese market. Journal of Financial Markets, 10(4):391-415.

Cheung, Y., Chinn, M. D., and Garcia Pascual, A. I. (2005). Empirical exchange rate models of the nineties: Are any fit to survive? Journal of International Money and Finance, 24(7):1150-1175.

Choe, H., Kho, B.-C., and Stulz, R. (2005). Do domestic investors have an edge? The trading experience of foreign investors in Korea. Review of Financial Studies, 18(3):795-829.

Duffuor, K., Marsh, I. W., and Phylaktis, K. (2012). Order flow and exchange rate dynamics: An application to emerging markets. International Journal of Finance $\mathcal{E} 3$ Economics, 17(3):290-304.

Dunne, P. G., Hau, H., and Moore, M. J. (2010). International order flows: Explaining equity and exchange rate returns. Journal of International Money and Finance, 29(2):358-386.

Dvořák, T. (2005). Do domestic investors have an information advantage? Evidence from Indonesia. Journal of Finance, 60(2):817-839.

Evans, M. D. D. and Lyons, R. K. (2002). Order flow and exchange rate dynamics. Journal of Political Economy, 110(1):170-180.

Evans, M. D. D. and Lyons, R. K. (2012). Exchange rate fundamentals and order flow. Quarterly Journal of Finance, 2(4):1250018-1-63.

Fan, M. and Lyons, R. K. (2003). Customer trades and extreme events in foreign exchange. In Mizen, P., editor, Monetary History, Exchange Rates and Financial Markets: Essays in Honour of Charles Goodhart, Volume Two, chapter 6, pages 160-179. Edward Elgar, Cheltenham. 
Forbes, K. J. and Warnock, F. E. (2012). Capital flow waves: Surges, stops, flight, and retrenchment. Journal of International Economics, 88(2):235-251. \{NBER\} Global.

Francis, B. B., Hasan, I., and Hunter, D. M. (2006). Dynamic relations between international equity and currency markets: The role of currency order flow. Journal of Business, 79(1):219258.

Froot, K. A. and Ramadorai, T. (2005). Currency returns, intrinsic value, and institutional investor flows. Journal of Finance, 60(3):1535-1566.

Gehrig, T. and Menkhoff, L. (2004). The use of flow analysis in foreign exchange: Exploratory evidence. Journal of International Money and Finance, 23(4):573-594.

Glosten, L. R. and Milgrom, P. R. (1985). Bid, ask and transaction prices in a specialist market with heterogenously informed traders. Journal of Financial Economics, 14(1):71-100.

Goodhart, C. A. E. (1988). The foreign exchange market: A random walk with a dragging anchor. Economica, 55(220):437-460.

Gyntelberg, J., Loretan, M., Subhanij, T., and Chan, E. (2009). Private information, stock markets, and exchange rates. Working Paper 271, Bank for International Settlements, Basel.

Gyntelberg, J., Loretan, M., Subhanij, T., and Chan, E. (2014). Exchange rate fluctuations and international portfolio rebalancing. Emerging Markets Review, 18:34-44.

Killeen, W. P., Lyons, R. K., and Moore, M. J. (2006). Fixed versus flexible: Lessons from EMS order flow. Journal of International Money and Finance, 25(4):551-579.

King, M. R., Osler, C. L., and Rime, D. (2013). The market microstructure approach to foreign exchange: Looking back and looking forward. Journal of International Money and Finance, 38:95-119.

Kyle, A. S. (1985). Continuous auctions and insider trading. Econometrica, 53(6):1315-1335.

Lyons, R. K. (2001). The Microstructure Approach to Exchange Rates. MIT Press, Cambridge MA.

Meese, R. A. and Rogoff, K. S. (1983). Empirical exchange rate models of the seventies: Do they fit out of sample? Journal of International Economics, 14(1-2):3-24.

Mishkin, F. S. (1982). Does anticipated monetary policy matter? An econometric investigation. Journal of Political Economy, 90(1):22-51.

Newey, W. K. and West, K. D. (1987). A simple, positive semi-definite, heteroskedasticity and autocorrelation consistent covariance matrix. Econometrica, 55(3):703-708.

Orwell, G. (1945). Animal Farm. A Fairy Tale. Secker and Warburg, London.

Osler, C. L. (2009). Foreign exchange microstructure: A survey of the empirical literature. In Meyers, R. A., editor, Encyclopedia of Complexity and Systems Science, pages 5404-5438. Springer, New York.

Osler, C. L. and Vandrovych, V. (2009). Hedge funds and the origins of private information in currency markets. Manuscript, Department of Economics, Brandeis University.

Pagan, A. R. (1984). Econometric issues in the analysis of regressions with generated regressors. International Economic Review, 25(1):221-247. 
Richards, A. J. (2005). Big fish in small ponds: The trading behavior and price impact of foreign investors in Asian emerging equity markets. Journal of Financial and Quantitative Analysis, 40(1):1-27.

Rime, D., Sarno, L., and Sojli, E. (2010). Exchange rate forecasting, order flow and macroeconomic information. Journal of International Economics, 80(1):72-88.

Rime, D. and Tranvåg, H. J. (2012). Flows of the Pacific: Asian foreign exchange markets through tranquility and turbulence. Pacific Economic Review, 17(3):434-466.

Sarno, L. and Sojli, E. (2009). The feeble link between exchange rates and fundamentals: Can we blame the discount factor? Journal of Money, Credit and Banking, 41(2-3):437-442.

Sarno, L. and Taylor, M. P. (2002). The Economics of Exchange Rates. Cambridge University Press, Cambridge UK.

Sarno, L. and Valente, G. (2009). Exchange rates and fundamentals: Footloose or evolving relationship? Journal of the European Economic Association, 7(4):786-830.

Siourounis, G. D. (2008). Capital flows and exchange rates: An empirical analysis. Working Paper 2008-028, University of Peleponnese, School of Management and Economics, Department of Economics, Tripolis, Greece.

Taechapiroontong, N. and Suecharoenkit, P. (2011). Trading performance of individual, institutional, and foreign investors: Evidence from the Stock Exchange of Thailand. International Research Journal of Finance and Economics, 75:157-174.

Tille, C. and van Wincoop, E. (2014). International capital flows under dispersed private information. Journal of International Economics, 93(1):31-49. 


\section{Recent SNB Working Papers}

2015-12 Jacob Gyntelberg, Mico Loretan and Tientip Subhanij: Private information, capital flows, and exchange rates.

2015-11 Philip Sauré: Time-intensive R\&D and unbalanced trade.

2015-10 Nikola Mirkov and Andreas Steinhauer: Ben Bernanke vs. Janet Yellen: Exploring the (a)symmetry of individual and aggregate inflation expectations.

2015-9 Aleksander Berentsen, Sébastien Kraenzlin and Benjamin Müller: Exit Strategies and Trade Dynamics in Repo Markets.

2015-8 Thomas Nitschka: Is there a too-big-to-fail discount in excess returns on German banks' stocks?

2015-7 Alin Marius Andries, Andreas M. Fischer and Pinar Yeşin: The impact of international swap lines on stock returns of banks in emerging markets.

2015-6 Jens H.E. Christensen and Signe Krogstrup: Transmission of Quantitative Easing: The Role of Central Bank Reserves.

2015-5 Petra Gerlach-Kristen and Seán Lyons: Mortgage arrears in Europe: The impact of monetary and macroprudential policies.

2015-4 Reto Foellmi, Sandra Hanslin and Andreas Kohler: A dynamic North-South model of demand-induced product cycles.

2015-3 Katarina Juselius and Katrin Assenmacher: Real exchange rate persistence: The case of the Swiss franc-US dollar rate.
2015-2 Lucas Marc Fuhrer, Basil Guggenheim and Silvio Schumacher: Re-use of collateral in the repo market.

2015-1 Pinar Yeşin: Capital flow waves to and from Switzerland before and after the financial crisis.

2014-13 Thomas Nitschka: Have investors been looking for exposure to specific countries since the global financial crisis? - Insights from the Swiss franc bond market.

2014-12 Christian Grisse and Thomas Nitschka: Exchange rate returns and external adjustment: evidence from Switzerland.

2014-11 Rina Rosenblatt-Wisch and Rolf Scheufele: Quantification and characteristics of household inflation expectations in Switzerland.

2014-10 Gregor Bäurle and Daniel Kaufmann: Exchange rate and price dynamics in a small open economy - the role of the zero lower bound and monetary policy regimes.

2014-9 Matthias Gubler and Christoph Sax: Skill-Biased Technological Change and the Real Exchange Rate.

2014-8 Tommaso Mancini Griffoli, Christoph Meyer Jean-Marc Natal and Attilio Zanetti: Determinants of the Swiss Franc Real Exchange Rate.

2014-7 Konrad Adler and Christian Grisse: Real exchange rates and fundamentals: robustness across alternative model specifications.

2014-6 Matthias Gubler: Carry Trade Activities: A Multivariate Threshold Model Analysis.

From 2015, this publication series will be renamed SNB Working Papers.

All SNB Working Papers are available for download at: www.snb.ch, Research

Subscriptions or individual issues can be ordered at: Swiss National Bank

Library

P.O. Box

$\mathrm{CH}-8022$ Zurich

Phone: +41446313284

Fax: +41446318114

E-mail: library@snb.ch 
